\title{
Historic resistance and new perspectives of International Commercial Arbitration in Brazil $^{1}$
}

\author{
Rafael Pellegrini Ribeiro
}

\section{- INTRODUCTION}

Brazil has never been recognized as a country where arbitration played a central role in dispute resolution. Nowadays, when International Commercial Arbitration is a common practice in the most industrialized nations, to have a good a good statute and patticipation in the main intemational conventions is a necessity to any country that desires to participate in the Intemational Trade scene.

Concerned with this facts, and noting that the country was too hostile to arbitration in such way that many industries were refraining to start business in the country for fearing the barriets that Brazil were imposing to arbitration, the Brazilian government decided to adopt measures towards a new approach on Alternative Methods of Dispute Resolution.

In this paper I will address the new measures taken by the Brazilian government in adopting the Law 9.307, published in the Brazilian Official Press in September 23, 1996. ${ }^{2}$ Firstly, I will discuss the history of arbitration in Brazil and to show why the country was labeled as a hostile place to enforce international arbitration awards. Secondly I will address the efforts made in adopting the new Brazilian Arbitration Law, or Law 9.307 (hereinafter BAL), to seek the theories and practice adopted by the most industrialized nations regarding arbitration in order to make the country a friendly place to International Arbitration, and in consequence to make Brazil a better environment to do business and also to diminish the workload of the judiciary. Finally I will concentrate on the recent adoption by Brazil of the United Nations Convention on the Recognition and Enforcement of Foreign Arbitral Awards (hereinafter the "New York Convention"). ${ }^{3}$ At this point

\footnotetext{
"Paper presented as final examination on the discipline "International Commercial Arbitration" in the Fall Semester of 2004 at Pace Law School in New York. I would like to thank Professor Edward V. Lahey who oriented me in this work and Professor Dr. Clatudia Lima Marques and the FIPSE/CAPES program of exchange of students between Brazil and the United States that made possible it for me to spend a semester at Pace Law School.

${ }^{2}$ Lei n. 9307, de 23 de setembro de 1996, D.O.U. de 24.09.1996, hereinafter BAL.

${ }^{3}$ United Nations Convention on the Recognition and Enforcement of Foreign Arbitral Awards, ratified by Brazil in July $23^{\text {rd }}, 2002$ by the "Decreto" n. 4311.
} 
Historic resistance and new perspectives of Intemational Commercial Arbitration in Braril

I will address mainly the point where the BAL or the practice by the courts is not yet in compliance with the New York Convention.

\section{History of Arbitration in Brazil}

\subsection{Evolution of Arbitration in Brazil}

Brazil has adopted arbitration for the first time while it still was a Portuguese colony as it had to follow all the legislation that was enacted in Portugal. In 1824 , with the proclamation of independence, a new constitution was made and arbitration was recognized in its article $160.4^{4}$ In the following years some laws made arbitration mandatory to some commercial cases. ${ }^{5}$

In 1867 a new law ${ }^{6}$ revoked the mandatory arbitration for certain commercial disputes, leaving arbitration voluntary to the parties. This law was the first step for more than a hundred years of hostility to atbitration in Brazil. Following this law, the country adopted a very strong policy based on the on the jurisdictional exclusivity of the courts. "This policy can be found in the most important codes and statutes until the BAL was enacted, as in the Brazilian Civil Code of 1916 and in the Brazilian Civil Procedure Code of 1939 and 1973..$^{\circ}$

In the other hand Brazil signed and ratified ${ }^{9}$ the Protocol of Geneva in September $24^{\text {th }}, 1923$. Who thought that this was a first step towards the development of arbitration in Brazil had to reconsider its position when Brazil enacted the Civil Procedure Code in 1939 that preempted the aforementioned Protocol in Brazil ${ }^{10}$.

Late after, in 1981, during some panels about arbitration and giving the concern that the failure to have a legislation pro arbitration was having bad effects in intemational trade in Brazil, the Brazilian government decided to pursue a friendlier legislation to arbitration. "In the same year the government published a first draft of legislation in arbitration seeking public comments. The draft was rejected the most well respected lawyers in the country. It was a real pity, because

\footnotetext{
4 Jose Alexandre Tavares Guerrelro, A Execucao Judicial de Decisoes Arbitrais, 75 Revista de Direito Mercantil 31, 31 (1999).

${ }^{5}$ Article 411 of the "Regulamento n. $737^{\prime \prime}$ enacted in January $25^{\circ *}, 1850$ and Articles 294 and 243 of the "Brazilian Commercial Code" enacted in 1850.

${ }^{6}$ Lei n. 1350, enacted in September $9^{\text {th }}, 1866$.

7 Ricardo Alvarenga. The 1996 Brazifian Law on Arbitration, 10 Worid Arb. Mediation Rep. 340, at $341(1999)$.

- Jurgen. Samtleben, Procedimento Arbitral No Brasil - O Caso "Lloyd Brasileiro Contra Ivarans Renderi" Do Supreior Tribunal De Justica, LXVIl Revista da Facuidade de Direito da Universidade de Sao Paulo 185, 210. (1999)

${ }^{9}$ Ratified by the "Decreto 21.167" enacted in May $22^{\text {nd }}, 1932$.

to Alvarenga, see supra note 6, at 342; Hermes Marcelo Huck, La Nouvelle Loi de L'arbitrage au Brésil, Bull. Assoc. Suisse Arb. 570, at 572 (Switz. 1997).

1 It Ineu Stegnet, Arbitragem Comercial Internacional, at 33 (LTR, São Paulo, 1998).
} 
the draft was based on the most advanced theories at the time, including enforcement of International Arbitral Awards without court recognition. But, at that time most of Brazilian lawyers were very proud with the new Civil Procedure Code and rejected the draft on the grounds that it was inconsistent with the new code. With so much criticism, the draft was abandoned.12

Six years later, in 1987, the government tried again publishing in the Official Press a new draft on arbitration. In this draft an International Arbitration Award was compared to an extra-judicial title. ${ }^{13}$ This means that if the award was in compliance with the requisites set in article 585 of the Civil Procedure Code ${ }^{14}$, the award could be enforced without any judicial recognition. There was only one other requisite, that the award must had been translated by an official translator and recognized by the Brazilian Consulate. But again, the draft was refused in the same grounds as it predecessor. ${ }^{15}$

In 1988 the government tried again, but at this time it was trying to amend the Civil Procedure Code and not to enact a specific legislation in arbitration. Very concerned with the two big failures in the past, at this time the government adopted lighter modifications. The problem was that this amendment had an unexpected side effect, and discouraged International Arbitration in Brazil even more. In its provisions it not included anything about enforcement of International Arbitration Awards and did anything about the requirement of double homologation, which was the practice in Brazil since ever. ${ }^{16}$

A new hope for arbitration in Brazil was given by the Liberal Institute of Pernambuco that under a project called "Operacao Arbiter" designed with public and private participation a draft on the matter. "The draft was based on the New York Convention, on the Panama Convention, on the UNCITRAL Model Law on Arbitration and on the Spanish Law on Arbitration. ${ }^{18}$ On April 27, 1992 the project was sent to congress where it was discussed for long four years until it was enacted under the number 9.307 on September 23, 1996. Just before the enactment of the BAL, Brazil signed and ratified The Inter-American Convention on International Commercial Arbitration ${ }^{19}$, but at the time, it was decided not to sign the New York convention.

\footnotetext{
12/d.

${ }_{13}$ Paulo Borba Casella, Arbitragem: Lei Brasileira e praxe intrenacional,57 ( LTR, Säo Paulo, 1999).

i4 Article 585, $\$ 2$ of the Brazilian Civil Procedure Code lays down the conditions for the enforcement of foreign extra-judicial executive titles: 1 . formal compliance with the rules of the country where the award was issued; and 2. an indication that Brazil would be the country where it would be enforced.

${ }^{15}$ Casella, supra note 12 , at 58.

is id.

${ }_{17}$ Alvarenga, see supra note 6 , at 342 .

${ }_{18}$ Maruska Guerreiro Lopes, La Nouvelle Lol Brésilienne sur L'arbitrage, 37 Dalloz Affaires 1, at 4 (Fr. 1997).

t9 Ratified on May $10^{\text {th }}, 1996$.
} 
Historic resistance and new perspectives of International Commercial

Arbitration in Brazil

\subsection{The historical problems of international arbitration in Brazil}

In Brazil, before the enactment of the $B A L$, there were two main problems with International Commercial Arbitration relating to the enforcement of international awards in the country: the non-recognition of the arbitration clause and the requirement of double homologation.

\subsubsection{Non-recognition of the arbitration clause}

Until the enactment of the $\mathrm{BAL}$, the arbitration clause was unenforceable, and there was a requirement that if the parties would prefer going to arbitration instead of going to courts they should renew their agreement just before commencing arbitration, that means after the dispute have arise. ${ }^{20}$ If a party refuses to comply with the arbitration agreement set in a contract, courts in Brazil could merely set damages for non compliance of a contractual clause, but it would never enforce it in the absence of an agreement made by the parties confirming their wish to settle a dispute by arbitration. " This was a major problem that almost banned International Commercial Arbitration from the country ${ }^{22}$. How can an International Company trust in an agreement that have to be confirmed after a dispute? In this case if on of the parties chooses not to go to arbitration, the worst that it could happen to him was to pay damages.

\subsubsection{Double homologation}

This was considered the major problem for International Commercial Arbitration in Brazil before the BAL. The double homologation, or double exequatur, consisted in the recognition of the award in the country where the arbitration took place and in Brazil, by the Brazilian Supteme Court, "Supremo Tribunal Federal" (hereinafter STF). In such way, the STF would only accept to submit the award to the tests of enforceability under the Brazilian Law if that award were previously recognized by a Court in the country where the arbitration took place. ${ }^{23}$

One of the problems that generated the need of double homologation is that an Arbitral Award held in a foreign country must be classiffed as a "Foreign judicial decision" according to the Brazilian Civil Procedure Code. ${ }^{24}$ In Brazil only two kinds of foreign acts could be enforced after recognition by a Brazilian court:

\footnotetext{
${ }^{20}$ Brest Fulkerson, A comparison of Commercial Arbitration: The United States \& Latin America, 23 Hous. J. Int'l L. 537, at 554 (2001).

2: Carlos Alberto Carmona, A Arbitragem no Brasil, Em Busca de Uma Nova Lei, 166 Jurisprudencia Brasileira, at $17-19(1999)$.

${ }^{22} / d$.

${ }^{23}$ Guido F. S. Soares, Arbitragens Comerciais Intemacionais no Brasil: Vicissitudes, 641 Revista dos Tribunais 38 , at 47 (1989).

24 Article 585 of the Brazilian Civil Procedure Code (1973).
} 
Foreign Judicial decisions and Executive Extra-judicial Titles. ${ }^{25}$ An Executive Extrajudicial Title is for example a Letter of Credit, which can be enforced directly just with the recognition by a Brazilin Court. A foreign judicial decision had to be recognized by the STF first, in order to become a Judicial Executive Title and then to be enforced. ${ }^{26}$

The problem happened when the legislator of the Brazilian Civil Procedure Code excluded the Foreign Arbitral award from the closed list of article 585, that lists all the Executive Extra-judicial titles, and it included in article 584 as a Judicial Executive Title. For these reason the only way that the STF could recognize a Foreign Arbitral Award was via a Foreign Judicial source, since it had to be a Foreign Judicial Decision in order to be recognized and not a mere award with no judicial recognition. ${ }^{27}$

Therefore, a foreign arbitral award could become enforceable only if legally considered a judicial executive title. To be considered a judicial executive title under the category of a foreign judicial decision, a foreign arbitral award had to go through double exequatur. First, it had to be recognized by the judiciary of the country where the foreign arbitral award was rendered. Then the foreign judicial decision had to be recognized by the President of the Brazilian Supreme Court. As is readily apparent, this process made any kind of international arbitration involving enforcement in Brazil extremely unattractive. ${ }^{28}$

This requirement was not only completely outdated, but also worked against the benefits of arbitration. The confidentiality of the award would be destroyed, as recognition by the Judiciary would make it public. The cost of arbitration would be increased by the obligation to submit the award to the judiciary. In addition, time savings would be lost because of the slowness of the recognition process and the possibility of a special appeal. ${ }^{29}$

In addition to the requirement of previous and valid recognition of the foreign arbitral award in the country where it was rendered, its recognition in Brazil had to comply with three other requirements. First, the decision had to be made by the competent judge and to respect Brazilian standards of due process. Second, the decision should not infringe upon national sovereignty or public policy. Finally, the decision should be notarized by the Brazilian consul and officially translated into Portuguese. ${ }^{30}$

\footnotetext{
25 Soares, see supra note 22 , at 48 .

${ }^{26}$ Article 35 of the BAL (1996).

${ }^{27}$ Lopes, see supra note 17, at 12.

2a Hermes Marcelo Huck, La Nouvelle Loi de L'arbitrage au Brésil, Bull. Assoc. Suisse Arb. 570 (Switz. 1997).

${ }^{29} \mathrm{fd}$.

${ }^{30}$ José Carlos Barbosa Moreira, La Nuova Legge Brasiliana Sullarbitrato, Rivista Del L'arbitrato (ttaly 1997).
} 
Historic resistance and new perspectives of International Commercial Arbitration in Brazil

There were three major problems of non-compliance with the due process requirements of Brazilian law for the recognition of foreign arbitral awards in the country. First, there was the lack of service by the Brazilian party through a letter rogatory to the Brazilian judiciary. Second, the foreign decision that recognized the foreign arbitral award without explaining its reasons was considered void. Finally, the Supreme Court required the evidence that this foreign decision was res judicata in its original country ${ }^{31}$. This last item occasioned severe problems of incompatibility, since countries have different concepts of res judicata. Those three requirements were the main reasons for the non-recognition of ten out of 14 cases presented to the Supreme Court over the course of 33 years. ${ }^{32}$

There were two problems inherent in the requirement of double exequatur, in addition to the nomal disadvantages for international arbitration already discussed above. One was that many countries did not require the recognition of the arbitral award for its enforcement and validity. Consequently, the award was made unenforceable since Brazil required the recognition of the foreign arbitral award by the foreign judiciary. ${ }^{33}$ The other was that Brazil could not recognize foreign arbitral awards issued by a private institution, for example the American Arbitration Association (AAA) or the International Chamber of Commerce (ICC). ${ }^{34}$ This rule flowed from the requirement of recognition. As the private institution would issue a foreign arbitral award that did not require recognition in the country of rendition, there would be no recognition by the foreign judiciary. With no recognition by the foreign judiciary, the foreign arbitral award could not be recognized in Brazil.

2. The Brazilian Law on Arbitration and its relations to International Commercial Arbitration

The Brazilian intent in enacting the BAL was to adopt the most up-to-date rules of arbitration that were used in the world. For that reason, the Brazilian legislator

\footnotetext{
3t This is compatible with what the Civil Code Introduction Law provided in Article 15, reinforced by the Supreme Court Ruling No. 420: "A foreign decision shall not be recognized if there is no evidence of res judicata." (free translation) Supreme Court Rulings are rules issued by the Supreme Court independent from any case; they do not make law nor are they binding. However, they establish the Supreme Court's preferred interpretation of the law. Practically, these rulings establish a uniform interpretation of the law by the courts, since the lower courts know that if they decide contrary to the Ruling, and the case ends up at the Supreme Court, the decision will be overruled.

32 See eg. STF cases: SE 1.982; SE 2.671; SE 2.424; SE $2.476 ;$ SE 2.597-3.

${ }^{33}$ Clovis V. Do Couto E Silva, O Juizo Arbitral no Direito Brasileiro, 620 Revista dos Tribunais 15 (1987).

${ }^{34}$ Soares, supra note 22, at 50. (STF case SE 1982, of June 3,1970, dealt with the award Northem international Co. Inc. v. Kern Mattes - issued by the AAA and STF Case SE 2006 of November 18, 1971 dealt with the award Otraco S.A v. Conoll, issued by The Cattle Food Trade Association).
} 
found inspiration on more than five instruments, as the New York convention and the UNCITRAL Model Law on Arbitration. ${ }^{35}$ This clearly shows that the goal of the Brazilian government was to adopt the most recent theories in arbitration, and to follow the international practice.

The BAL addresses all topics of arbitration, and it is very similar to many arbitration statutes around the world, since Brazil is not the only country that has found inspiration in the provision set by the UNCITRAL or by the New York convention. Given that, in the BAL there is no gteat innovation or differences from the aforementioned instruments, so in this work $I$ will not address the procedural provisions of the BAL, since they are quite similar to most of the arbitration statutes in the world, as for example the United States Federal Artitration Act ${ }^{36}$. For the matters of this work, I will discuss only the provisions that deal with the recognition and enforcement of international arbitral awards, which are listed in Chapter VI of the BAL. It is also important to discuss the practical response of the public and private sectors to the BAL.

\subsection{Unconstitutionality of the Brazilian Arbitration Law}

One of the first reactions about the BAL was a very strong movement that wanted to declare the statute unconstitutional, since that found that some articles, in special article 7, were inconsistent with the provisions on the Constitution that granted full access to courts ${ }^{37}$. Article 7 of the BAL states that courts have to compel arbitration, issuing a judgment that operates as a specific arbitral submission, if the parties have falled to provide for the applicable procedural or substantive rules. The issue of unconstitutionality of the BAL is, fortunately, already overcome. STF, in several instances, including in the judgment of the incident of unconstitutionality ${ }^{38}$, ratified the understanding that under the provisions of the BAL and those disputes that were considered arbitrable under the Brazilian Law may go to arbitration.

STF held that the BAL does not infringe art. 5, item XXXV of the Brazilian Constitution, which states that "the law will not exclude from the consideration of the Judiciary any lesion or threaten to any right". "The goal of this provision is to prevent laws that allegedly suppress the rights of citizens to resort to the judiciary. ${ }^{39}$

\footnotetext{
35 Guerreiro, see supra note 17.

${ }^{36}$ Federal Arbitration Act, 9 U.S.C. \$1 (1999).

${ }^{37}$ Mary B. Brusewitz, Brazif Ceases its Antipathy Toward ADR, The National Law Journal, Section C (1996).

38 STF case SE 5206.

39 Busewitz, see supra note 36 .
} 
Historic resistance and new perspectives of International Commercial Arbitration in Brazil

The discussion in the STF was mainly based on the provision on article 7 of the BAL. In one case regarding recognition of foreign arbitral awards ${ }^{40}$, Justice Sepúlveda Pertence argued for the unconstitutionality of article 7 , since it would characterize a generic waiver, of an indefinite object, to the assurance of access to the jurisdiction. The waiver to the right of action does not exist "in abstracto".

In the other hand, Justice Nelson Jobim contested with the argument that the Constitution does not prohibit the parties from agreeing to extrajudicial forms of settlement of disputes that may arise within the scope of a certain agreement. Justice Ilmar Galvão adds that :

"the Brazilian judge cannot interpret the new law to make innocuous the provision that equalizes the clause, giving it effectiveness, even if by resorting to the judicial judgment, under penalty of showing to be insensitive to the changes that occurred in the same period in several laws, even because, including, it is in line with the international texts in force in Brazil, such as the Protocol of Geneva of 1923 and the Inter American Convention on Commercial Arbitration done in Panama". 41

Moreover, Justice Ellen Gracie ponders that:

"denying the possibility that the commitment value to have full validity and give raise to the specific execution implies to privilege the defaulting party and denying the subnittal to the quick way of dispute settlement, a mechanism for which it freely opted, upon the execution of the agreement where this provision was inserted. It is giving the defaulting party the power of voiding a condition that - given the nature of the involved interests - could have been deemed to be essential for the agreement." 42

In the other votes, Justices Celso de Mello and Marco Aurélio Mello stated the same understanding declaring the constitutionality of article 7 and, in consequence, to all the extent of the BAL.

\subsection{Recognition and enforcement of International Arbitral Awards}

One of the main aims in the enactment of the BAL was to open the country to a great number of investors that the country had lost just because the hostility to arbitration, mainly because the problems of the non-binding nature of the arbitration

\footnotetext{
40 STF case, see supra note 37.

41 Free translation of the decision.

42 jd.
} 
agreement and the double homologation. So, the main objective of the BAL was to create a favorable environment for International Commercial Arbitration in order to encourage its use. ${ }^{43}$

Another goal of the BAL was to release the Brazilian Judiciary from International Commercial cases, which normally are very complex. These kinds of cases are better dealt by specialized agents, as arbiters, and not by common judges. In the same way, in developing arbitration in Brazil, the government is also diminishing the workload of the courts. ${ }^{44}$

With the enactment of the new law, Brazil recognized the autonomous nature of an arbitration clause in a contract as a binding agreement. With the BAL, Brazil also ended with the biggest barrier to International Commercial Arbitration, which was the requirement of the double homologation. The BAL dispensed the recognition by the foreign judiciary, but at the same time it maintained the requirement for the recognition of foreign arbitral awards by the STF ${ }^{45}$

This was considered a problem by some international critics. If Brazil was trying to give a big step towards the most recent theories in arbitration, why it adopted a so unusual practice, as it is the homologation by the Supreme Court?

The legal literature in Brazil identifies two ways of recognizing a foreign arbitral award different from the double exequatur. First, thete is the "homologacao" (homologation) that consists of a special process of the same name and transforms the foreign arbitral award into a national enforceable title ready to be enforced. This homologation is an initial and distinct process that precedes the enforcement; Brazil adopted this system to recognize foreign arbitral awards. ${ }^{46}$ The second way is a natural assimilation and recognition of the foreign arbitral award directly in the enforcement process, also known as direct recognition. This second process is the one used in most countries and is totally independent from the first one. The second system of recognition makes homologation totally dispensable. ${ }^{47}$

It seems quite obvious that direct recognition meets more adequately the goals of an arbitration process, since it reduces time and cost. On the other hand, the old double exequatur system was at least twice as expensive as and slower than the sole homologation tequired by the BAL in Article $35.4^{48}$ That article was definitely an advance in terms of easing the recognition of foreign arbitral awards, but is not yet in compliance with the modern practice of international arbitration.

\footnotetext{
43 Arnold Wald, Some controversial aspects of the new Brazilian Arbitration Law, 31 U. Miami Inter-Am. L. Rev. 223, at 226 (2000).

${ }^{44} / \mathrm{d}$, at 238 .

${ }_{45}$ Article 35 of the BAL states that: "To be recognized or executed in Brazil, the foreign arbitral judgment is subject solely to homologation by the Supreme Federal Tribunal."

45 Article 35 of the BAL

${ }^{47}$ Guido F. S. Soares, O Supremo Tribunal Federal e as Arbitragens Comerciais Internacionais: "De Lege Ferenda", 642 Revista dos Tribunais 38, 39 (1989).

${ }^{43}$ Article 35 of the BAL
} 
Historic resistance and new perspectives of International Commercial Arbitration in Brazil

The question temains, then, why did Brazil adopted a middle solution, when it could have gone further in its reforms and adopt the "direct recognition" system? By continuing to require recognition of the foreign arbitral award by the Brazilian Supreme Court, the legislature chose a less favorable system for international commercial arbitration. Assuming that this was an intentional choice, since the other option, the "direct recognition," was already a worldwide practice, what becomes intriguing are the reasons why this choice was made.

\section{Brazil and the New York Convention}

After the rough years after the enactment of BAL, with all the problems involving the unconstitutionality of some provisions in the statute, the Brazilian govermment tried to show, once more, that Brazil is trying all efforts to make the country more attractive to business who rely in arbitration, and to show that the international standards in arbitration are applied also in Brazil by ratifying the New York Convention. In this part of the work I will address the two main aspects that are being discussed relating to the recent ratification of the New York Convention by Brazil.

\subsection{Grounds for refusal to recognize or enforce arbitral awards}

As aforementioned, many principles of the Convention were adopted in the BAL, even prior to the ratification by Brazil. Articles 37 to $39^{49}$ Article 37. The 49 Article 37. The homologation of a foreign arbitral "judgment" shall be requested by the interested party. The initial complaint should contain the requirements of procedural law in conformity with Article 282 of the Code of Civil Procedure and shall necessarily be accompanied by:

1 - the original of the arbitral "judgment" or a duly certified copy, authenticated by the Brazilian Consulate and accompanied by an official translation;

1I - the original of the arbitration agreement or a duly certified copy, accompanied by an official translation.

Article 38. Homologation may only be denied for recognition or execution of a foreign arbitral "judgment" when the defendant shows that:

1 - the parties lacked capacity in the arbitration agreement;

II - the arbitration agreement was invalid according to the law to which the parties submitted themselves, or, in default of such showing, by virtue of the law of the country where the arbitral "judgment" was rendered;

III - there was no notification of the designation of the arbitrator or of the arbitration proceeding, or the principle of the adversary system was violated, making an ample defense impossible;

$N$ - the arbitral "judgment" exceeded the limits of the arbitration agreement, or it was not possible to separate the part that exceeded it from that which was submitted to arbitration;

$V$ - the institution of the arbitration was not in accordance with the arbitral submission or the arbitration clause;

VI - the arbitral judgment has not yet become obligatory for the parties, has been annulled, or, it has been suspended by a court of the country where the arbitral judgment was rendered.

Article 39. Homologation shall aiso be denied for recognition or enforcement of the foreign arbitra! "judgment" if the Supreme Federal Tribunal determines that:

1 - according to Brazilian law, the object of the dispute was not susceptible to being resolved by arbitration;

II - the decision offends national public policy. 
homologation of a foreign arbitral "judgment" shall be requested by the interested party. The initial complaint should contain the requirements of procedural law in conformity with Article 282 of the Code of Civil Procedure and shall necessarily be accompanied by:

I - the original of the arbitral "judgment" or a duly certified copy, authenticated by the Brazilian Consulate and accompanied by an official translation;

II - the original of the arbitration agreement or a duly certified copy, accompanied by an official translation.

Article 38. Homologation may only be denied for recognition or execution of a foreign arbitral "judgment" when the defendant shows that:

seem to be a ditect translation of articles IV and $V$ of the New York Convention. They cover the issues of how to recognize and enforce a foreign arbitral award, and when the recognition and enforcement can be refused. ${ }^{50}$

\subsubsection{Public Policy}

Another issue that can cause some problems to Intemational Arbitration that has to be enforced in Brazil is the interpretation of public policy. Although the principle in the New York Convention is to refuse enforcement of an award that goes against "the public policy of that country"s!, there is no doubt that the intention of the drafters of the New York Convention was to create a pro-enforcement atmosphere for international commercial arbitration. This implies that the drafters intended to encourage a narrow construction of the public policy defense. ${ }^{52}$

The United States of America, following the New York Convention, established in its own courts the interpretative line that the recognition and enforcement of foreign arbitral awards should only be denied when it would cause the violation of the "most basic notions of morality and justice." public policy concept does not involve national political interests or their protection.

\footnotetext{
Sole paragraph. Effective service on a party resident or domiciled in Brazll, in the form of the agreement to arbitrate or the procedural law of the country where the arbitration was carried out (including allowance of service by mail with unequivocal proof of receipt), shall not be considered offensive to national public policy, so long as the Brazilian party is assured ample time for the exercise of the right of defense.

${ }_{50}$ Gary B. Born, International Commercial Arbitration, at 795 (Kluwer Law international, 2001 ).

5: Article V.2(b) of the United Nations Convention on the Recognition and Enforcement of Foreign Arbitral Awards.

${ }^{52}$ Parsons \& Whittemore Overseas Co., Inc v. Société Général de L'Industrie du Papier, 508 F.2d 969, at 974 (2d Cir. 1974).

${ }^{53} / d$.
} 
Historic resistance and new perspectives of Intemational Commercial

Arbitration in Brazil

In Brazil, the concept of public policy is still the subject of many controversies. Public policy is an ambiguous concept, particularly in relation to international acts. Fortunately, Brazil does not interpret this concept as a protective instrument for national political interests. ${ }^{54}$ Also called the social order, public policy has as a core definition the respect for the legal institutions and for the basic values of Brazilian society. But, in many cases, some controversial issues have been treated as a public policy matter, in order to refuse to recognize or enforce some International Arbitral Awards ${ }^{55}$. In this sense, Brazil still needs to adopt a more strict definition in order to make this process more predictable and easier,

3.1.2 Disputes not capable of settlement by arbitration under Brazilian law

Finally, Brazil has a very strict policy of the matters that can be arbitrated. According to the New York Convention article V:

"2. Recognition and enforcement of an arbitral award may also be refused if the competent authority in the country where recognition and enforcement is sought finds that:

(a) The subject matter of the difference is not capable of settlement by arbitration under the law of that country"

This means that many awards cannot be enforced because the subject matter of the award cannot be arbitrated in Brazil. Under Brazilian law, arbitration can only be used to resolve disputes "relating to arbitrable patrimonial rights," ${ }^{56}$ which arguably refer to alienable property rights, both tangible and intangible. Labor matters are generally under the exclusive jurisdiction of the domestic courts, though some arbitration agreements in the context of collective bargaining agreements are enforceable.

Under the United States Federal Arbitration Act, matters of commerce can be arbitrated, with the exception of some employment contracts. ${ }^{57}$ As the Commerce Clause of the United States Constitution ${ }^{58}$ is read broadly, most civil matters are considered arbitrable in the United States. The United States Supreme Court has allowed arbitration agreements to be upheld in employment contracts, ${ }^{60}$ even if such agreements are a contingency for employment. ${ }^{61}$

\footnotetext{
54 Carlos Nehring Netto, The New Brazilian Arbitration Law, I.C.C. Int'l C.. Arb. Bull. (Special Supplement: International Commercial Arbitration in Latin America,1997)

${ }^{55}$ id.

${ }^{56}$ Article 1 of the BAL (1996).

57 Federal Arbitration Act, 9 U.S.C. $\$ 1$ (1999).

${ }^{58}$ U.S. Const. art. $1, \S 8, \mathrm{cl}, 3$.

59 Wickard v. Filburn, 317 U.S. 111, 124-25 (1942).

60 Circuit City Stores, Inc. v. Adams, 532 U.S. 105, $112(2001)$.

${ }^{21}$ id., at 109-10.
} 


\subsection{Homologation by the Brazilian Supreme Court}

Another issue that has been raised by Brazilian commentators is the legitimacy of the requirement of homologation for foreign arbitral awards under the provisions of the New York Convention ${ }^{62}$.

Article III of the convention states that:

"Each Contracting State shall recognize arbitral awards as binding and enforce them in accordance with the rules of procedure of the territory where the award is relied upon, under the conditions laid down in the following articles. There shall not be imposed substantially more onerous conditions or higher fees or charges on the recognition or enforcement of arbitral awards to which this Convention applies than are imposed on the recognition or enforcement of domestic arbitral awards." (Emphasis added).

The BAL has differentiated the treatment between national and foreign awards, since the arbitral decisions awarded outside the Brazilian territory must be homologated ${ }^{63}$ In the other hand, the domestic decisions can go directly to the enforcement process, since they are recognized as an Executive Judicial Title ${ }^{64}$. The homologation process for sure can cause an undue delay and may cost more.

Some lawyers may say that the country has the right to impose it own requirements for recognition, and a "more onerous condition" would be an extreme situation as existed in the past with the double homologation" Others say that Brazil is in discordance with the New York convention, since the requirement of homologation is just requisite for arbitral decisions awarded outside the country ${ }^{66}$

Thus, there is a discussion in this topic also, and in the position of a foreign investor or someone interested in International Commercial Arbitration this aspect is very relevant, and is clear that the homologation by the STF to foreign awards is considered a more onerous condition in the recognition of the award.

\footnotetext{
$\overline{62}$ Joăo Bosco Lee, Le Nouveau Régime de L'arbitrage au Brèsli, Revue De L'arbitrage 157 (Fr. 1997)

63 Stegner, see supra note 10, at 300 .

${ }^{64} / d$.

${ }^{65}$ Jose Carlos de Magalhães, Solução e prevenção de hitigios internacionais, at 450, volume 1 (NECIN, São Paulo, 1998).

${ }^{66} / d$.
} 
Historic resistance and new perspectives of International Commercial Arbitration in Brazil

\section{- Conclusion}

Brazil has definitely taken some steps against its past isolationist attitude toward arbitration. But as seen in this brief work many issues are still creating difficulties to the recognition and enforcement of international arbitral awards.

Nowadays, Brazil is considered the $8^{\text {th }}$ economy in the world, but in terms of arbitration the country is so far down in the list. If Brazil wants to open even more for the International Trade one of the steps that it should take is to reconsider some provisions of the $B A L$, and to change some practices that are not consistent with the international standards, as the requirement of homologation by the Supreme Court.

In the last 10 years, with the enactment of BAL and the ratification of the New York Convention Brazil advanced a lot more than ever regarding arbitration, but these changes wete not sufficient in order to make Brazil a safe place for arbitration.

In order to change that, Brazil have to start a reform not only in statutes that together with the BAL affect arbitration, as the Brazilian Civil Procedure Code, but it has also to start changing the case law in the Supreme Court, that shall ask less requirements and formalities to recognize an international arbitral award. Brazil has also to adapt all the legislation and the procedure of recognition in order to fulfill the requirements set in the New York Convention, which since last years is binding in Brazil as law of the land. ${ }^{67}$

Therefore, there was a big advance, but it was insufficient to fulfill the main o objective, that was to make Brazil a safe place to enforce arbitration. Is considerable the loss of commerce that Brazil is losing by refraining to abandon so antique practices, and a recommendation to the Brazilian government is to continue trying to persuade the judiciary of the positive characteristics that arbitration can bring.

${ }_{67}$ Guido F. S. Soares, The treat-making process under the 1988 Federal Constitution of Brazil, 67 Chi. Kent. L. Rev. 495, at 502 (1991). 